\title{
Does Globalization Affect Crime? Theory and Evidence
}

\author{
Arghya Ghosh \\ University of New South Wales \\ Peter E. Robertson* \\ The University of Western Australia \\ Marie-Claire Robitaille \\ The University of Nottingham, Ningbo, China
}

14-May-2015

\begin{abstract}
Globalization skeptics argue that trade liberalization has high social costs, including an increase in expropriative behavior such as civil-conflict, coercion of labor and crime. We show that a theoretical relationship between trade and expropriation exists, but the sign differs for developed and developing economies. We verify this empirically using data on crime rates. Specifically we find trade liberalization, as measured by both higher openness and lower import duty rates, tends to increase burglaries and theft in very labor abundant countries. For other countries, however, we find that trade liberalization has either a small negative effect on crime, or no effect, depending on the country's capital abundance.
\end{abstract}

Keywords: Expropriation, International Trade, Globalization, Crime.

JEL: O1, F1.

\footnotetext{
*Corresponding Author; P. Robertson, Economics, School of Business, University of Western Australia, Perth. Email: peter.robertson@uwa.edu.au.
} 


\section{Introduction}

There is a long history of economic thought that expresses scepticism over the benefits of trade liberalization on non-economic grounds (Irwin 1996, Findlay and O'Rourke 2007). This scepticism extends to the contemporary globalization debate where some authors such as Rodrik (1997) have suggested that the economic gains from trade might be dominated by other considerations such as crime and social conflict. ${ }^{1}$ In particular, in an environment where law enforcement is imperfect or costly, agents can engage in expropriation or predation rather than production. Recent studies by Ghosh and Robertson (2012), Dal Bo and Dal Bo (2011) and Dube and Vargas (2011) show that the impact of trade on expropriation may be positive or negative depending on whether a country is labor or capital abundant. These papers thus raise interesting, but un-tested, propositions regarding the effects of trade liberalization on crime. In particular they suggest that possibility that the effects of trade liberalization on expropriative activity will differ between developed and developing economies. ${ }^{2}$

The aim of this paper is to explore this relationship theoretically and empirically using international data on crime rates. Crime is perhaps the most pervasive form of expropriation and there is an extensive literature on the economics of crime following Becker (1968) and Ehrlich (1973). In particular Imrohoroglu, Merlo and Rupert (2004) have emphasized the importance of law enforcement activities, as well as economic activity, and inequality in explaining crime trends. Likewise there is an extensive literature on how trade affects wages and inequality. Nevertheless the link between trade liberalization and crime, and whether it differs across the development spectrum, has not been explored in the literature. ${ }^{3}$

Perhaps the body of work closest to our own is the recent literature on external shocks and economic conflict, such as Miguel, Satyanath and Sergenti (2004), Collier and Hoeffler (2004), Besley and Persson (2008), Bruckner and Ciccone (2010), and Dube and Vargas (2011). These studies seek to identify the determinants of conflict and civil war. Across these studies there is a relatively robust finding that changes in external prices

\footnotetext{
${ }^{1}$ See also Deardorff (2000), Wolf (2004) and Bhagwati (2004) for overviews of the globalization debate.

${ }^{2}$ Other models that look at similar issues, including predation, include Anderson and Marcouiller (2005), Anderson and Bandiera (2006), Dodson (2002) and Demombynes and Ozler (2005). Similarly Dutt, Mitra and Ranjan (2009) consider the impact of openness on unemployment, allowing for the sign to differ between capital and labor abundant countries.

${ }^{3}$ In particular an extensive literature exists on the determinants of crime across countries, focusing on factors such as the rate of growth (Pyle and Deadman 1994, Cook 2010), unemployment rates (Bushway, Cook and Phillips 2010), urbanization (Glaeser and Sacerdote 1999, Fajnzylber, Lederman, Loayza, Reuter, Roman and Gaviria 2000) and the level of development (Soares 2004).
} 
are associated with changes in conflict, particularly in African countries.

Insofar as conflict and crime are both types of expropriative activity, the present study can be thought of as being complementary to this literature. Focusing on crime has an advantage because of the extensive availability of comparable data relative to other forms of expropriative activity such as civil-conflict, coercion and piracy. Finally, as we illustrate in our theoretical section, the economics of crime literature provides some interesting, yet untested, propositions regarding the heterogeneous responsiveness of crime rates to trade liberalization across countries depending on their labor abundance.

The aim of this paper, therefore, is to examine whether trade liberalization has affected the rates of crime. The empirical section test this proposition with respect to theft and burglaries, using a panel data of 72 countries over the period 1980 to 2008. We find that trade liberalization increases crime rates in very labor abundant countries, but has a statistically insignificant effect on crime for most countries with intermediate levels of labor abundance. We also find some evidence to suggest that trade liberalization may reduce crime in very capital abundant countries.

The results hold for different specifications of the model including different measures of crime and trade liberalization. We also explore other related explanations such as the role of institutions and the relationship between crime and inequality. Finally we also control for endogeneity that may arise in two distinct forms. First we consider the potential endogeneity of the trade variables policy variables by using instruments lagged values and also the predicted value of openness, based on the geographic and historical characteristics. In addition we consider the possibility, suggested in the crime literature, that past crime rates may affect the current crime rate. We use an Arellano and Bond (1991) estimator to control for differences in past crime rates. We find consistent support for our the hypothesis that trade liberalization increases crime rates in very labor abundant countries; reduce crime in very capital abundant countries, but has little no effect for countries with average capital abundance.

The rest of the paper is organized as follows. First, to motivate the empirical analysis, we develop a simple model that shows how trade liberalization can affect expropriation. This model is presented in Section 2, and is followed by a discussion of the data and empirical strategy, including data reporting issues, in Section 3. The results are discussed in Sections 4 and 5. Section 6 then investigates endogeneity issues and Section 7 concludes. 


\section{A Model of Crime and Trade}

Consider a small open economy with a unit measure of identical individuals. ${ }^{4}$ Each individual has $\bar{L}$ units of labor and $\bar{K}$ units of capital, the returns (per unit) to which are denoted by $w$ and $r$ respectively. There are two tradable goods, an exportable and an importable denoted by $x$ and $m$ respectively. Let $p_{x}$ and $p_{m}$ respectively denote the world price of the exportable and importable. Choosing units appropriately for the two goods we set $p_{m}=p_{x}=1$. We assume that the import-competing sector is tariff protected and let $p(>1)$ denote the tariff-inclusive price of the importable good faced by domestic consumers.

Both $x$ and $m$ are produced under constant returns to scale and perfect competition using labor and capital. Perfect competition in both these sectors imply that unit cost equals price:

$$
\begin{aligned}
c_{x}(w, r) & =1, \\
c_{m}(w, r) & =p,
\end{aligned}
$$

where $c_{x}(w, r)$ and $c_{m}(w, r)$ denote the unit cost functions for $x$ and $m$ respectively.

Unlike the standard Heckscher-Ohlin framework, we assume law enforcement is not perfect. As a consequence, in equilibrium, some resources will not be engaged in productive activities. Each individual endowed with $\bar{L}$ units of labor and $\bar{K}$ units of capital faces an effective choice between employing labor and capital in producing goods or services and expropriating income from other agents.

\subsection{Expropriation}

We assume that, in their attempt to expropriate income, each individual can target only one individual and can only be targeted by one individual. The probability of successfully expropriating another individual's market income depends on the resources committed to expropriation. Suppose individual $i$ uses $L_{e}^{i}$ units of labor and $K_{e}^{i}$ units of capital in expropriation. The production function for expropriation is $e\left(L_{e}^{i}, K_{e}^{i}\right) \equiv e^{i}$, where the following assumptions hold: (i) $e(0,0)=0$, (ii) $e^{i}$ is homogenous of degree one, (iii) $\frac{\partial e(., .)}{\partial F_{e}^{i}}>0, \frac{\partial^{2} e(., .)}{\partial F_{e}^{i}}<0 ; \quad F \in\{L, K\}$.

\footnotetext{
${ }^{4}$ This builds on recent papers by Ghosh and Robertson (2012) and Dal Bo and Dal Bo (2011) with a view to providing a simpler, but also more accessible, statement of the relationship between the impact of trade on crime at different levels of economic development.
} 
The unit cost function associated with this expropriation technology, which captures the minimum income that an agent $i$ has to forego to produce $e^{i}=1$, is then given by

$$
c_{e}^{i}(w, r)=\min \left\{w L_{e}^{i}+r K_{e}^{i} \mid e^{i}=1\right\} .
$$

The value of $e^{i}$ determines the probability of $i$ 's success in expropriation. More specifically, an agent $i$ succeeds in expropriation with probability $\phi\left(e^{i}\right)$ where $\phi($.$) satisfies the$ following properties: (i) $\phi(0)=0$, (ii) $\phi^{\prime}\left(e^{i}\right)>0, \phi^{\prime \prime}\left(e^{i}\right)<0$, and (iii) $\phi\left(e^{i}\right)<1$. The first two properties are standard. The third one says that there is a strictly positive probability of failure of expropriation even if all resources are devoted to expropriation.

\subsection{Law Enforcement Services}

Individuals buy law enforcement services to reduce the probability of being expropriated. Income from productive activities for an individual $i$ is

$$
\omega^{i} \equiv w L^{i}+r K^{i}
$$

where $L^{i} \equiv \bar{L}-L_{e}^{i}$ units of labor and $K^{i} \equiv \bar{K}-K_{e}^{i}$ units of capital are engaged in productive activities. A fraction $\gamma \in(0,1)$ of this income is subject to potential expropriation and hence the actual income from productive activities may be less than $\omega^{i}$. Nevertheless $\omega^{i}$ may also be realized if the act of expropriation is verified by a court.

We assume that each individual $i$ buys $z^{i}(\geq 0)$ units of law enforcement services, which we think of as a bundle of security and legal services. Naturally, the higher the level of $z^{i}$, the higher the probability that the claim of expropriation by individual $i$ is successfully verified in the court. Let $\alpha\left(z^{i}\right)$ denote that probability which satisfies the following plausible conditions: (i) $\alpha(0)=0$, (ii) $\alpha\left(z^{i}\right)<1$ for all finite $z^{i}$, and (iii) $\alpha^{\prime}\left(z^{i}\right)>0$, $\alpha^{\prime \prime}\left(z^{i}\right)<0$. Let $z \equiv \int_{0}^{1} z^{i} d i$ denote the overall level of law enforcement services in the economy. Like $x$ and $m, z$ is competitively produced under constant returns to scale. The relevant pricing equation is

$$
p_{z}=c_{z}(w, r)
$$

where $c_{z}(w, r)$ and $p_{z}$ respectively denote the unit cost function and the price of $z{ }^{5}$

\footnotetext{
${ }^{5}$ The existence of a market for $z$ is not necessary for our results. Analogous to the contest/conflict literature we can think of $z^{i}$ as $i$ 's investment in protection of property, or endowments, which uses both labor and capital. Unlike $x$ and $m, z$ is non-traded. For an alternative approach to modeling law enforcement provision through voting see Imrohoroglu, Merlo and Rupert (2000).
} 


\subsection{Income and Utility}

The net potential income of $i$ from productive sources is $\omega^{i}=w \bar{L}+r \bar{K}-c_{e}(.) e^{i}$. As explained above, a fraction of that income, $\gamma \omega^{i}$, is subject to potential expropriation by individual $j$. Similarly, an individual $i$ attempts to expropriate $\gamma \omega^{k}$ from individual $k$. Taking the probabilities of retaining those incomes into account (see Appendix A for details) and deducting the expenditure on legal services, $p_{z} z^{i}$, $i$ 's expected disposable income can be expressed as

$$
\bar{y}_{d}^{i}=\omega^{i}\left(1-\gamma \phi\left(e^{j}\right)\left(1-\alpha\left(z^{i}\right)\right)\right)+\gamma \omega^{k} \phi\left(e^{i}\right)\left(1-\alpha\left(z^{k}\right)\right)-p_{z} z^{i}
$$

Assume preferences are homothetic. Then we can write $i$ 's expected indirect utility $V^{i}$ as $v(p) \bar{y}_{d}^{i}$ where $v(p)$ is decreasing in $p$.

\subsection{Equilibrium}

Each individual $i$ chooses $e^{i}$ and $z^{i}$ to maximize $V^{i} \equiv v(p) \bar{y}_{d}^{i}$. We focus on symmetric equilibrium where $e^{i}=e$ and $z^{i}=z$ for all $i$. Rearranging the first-order conditions, $\frac{\partial V^{i}}{\partial e^{i}}=0$ and $\frac{\partial V^{i}}{\partial z^{i}}=0$, and evaluating at $\left(e^{i}, z^{i}\right)=(e, z)$ we get

$$
\begin{aligned}
\phi^{\prime}(e) \frac{1-\alpha(z)}{1-s} & =\frac{c_{e}}{\gamma \omega}, \\
\phi(e) \alpha^{\prime}(z) & =\frac{p_{z}}{\gamma \omega} .
\end{aligned}
$$

where $s \equiv \gamma \phi(e)(1-\alpha(z))$ denotes the expected share of income obtained though expropriation. Figure 1 below shows these two equations.

(Figure 1 about here)

The downward sloping curve $E E$ depicts (6) which captures the optimal level of expropriation for a given level of $z$. As $z$ increases, (i) expected income from expropriation declines, and (ii) more income from productive activities is retained. Both (i) and (ii) reduce incentives to engage in expropriation and consequently $e$ declines.

The upward sloping curve $Z Z$ depicts (7) which captures the relationship between the demand for law enforcement and expropriation. There are two forces at work. First the higher the level of expropriation the higher is the demand for legal services. This effect suggests a positive relationship between $e$ and $z$. There is a second less obvious effect 
however. A higher $e$ implies a lower $\omega=w \bar{L}+r \bar{K}-c_{e}()$.$e . Thus there is less income to$ protect which reduces the marginal benefit from legal services. The second effect suggests that $e$ and $z$ might be negatively related. We assume that the first effect dominates and draw $Z Z$ as an upward sloping line in $(e, z)$ space. ${ }^{6}$ The intersection of $E E$ and $Z Z$ gives equilibrium values $\left(e^{*}, z^{*}\right)$.

\subsection{Trade Liberalization}

We represent trade liberalization as a fall in $p$ - the price of the importable good. A fall in $p$ affects $\frac{w}{r}$ which in turn affects the opportunity cost of expropriation $\left(c^{e}\right)$, the price of legal services $\left(p_{z}\right)$ and the income from productive activities $(\omega)$. Consequently, trade liberalization alters the equilibrium level of expropriation, $e^{*}$. However, as $\frac{w}{r}$ increases in countries exporting labor-intensive goods and decreases in others, the effect of trade liberalization on $e^{*}$ can qualitatively differ across countries.

To fix ideas, consider a developed country $D$ that exports capital intensive goods and a developing country $G$ that exports labor intensive goods. Let $\frac{K^{D}}{L^{D}}=k^{D}$ and $\frac{K^{G}}{L^{G}}=k^{G}$ respectively denote the capital-labor ratio (in productive activities) in the developed and the developing country. Also, let $k_{z}^{i}$ and $k_{e}^{i}$ respectively denote the equilibrium capitallabor ratio in expropriation and the law enforcement sector of country $i \in\{G, D\}$. Assume the following ranking -

$$
\max \left\{k_{z}^{D}, k_{z}^{G}\right\}<k^{G}<k^{D}<\min \left\{k_{e}^{D}, k_{e}^{G}\right\}
$$

which says that (a) the developing country $G$ is relatively labor-abundant and (b) the law enforcement sector is relatively labor-intensive.

First consider the developing country $G$ that exports a labor-intensive good. A fall in $p$ raises $\frac{w}{r}$. Since expropriation is relatively capital-intensive (i.e. $k^{G}<k_{e}^{G}$ ), the opportunity cost of crime relative to income from productive activities, $\frac{c_{e}}{\omega}$, decreases. Incentives to expropriate increases and the downward sloping $E E$ curve shifts right. Similarly, since law enforcement is relatively labor-intensive, $\frac{p_{z}}{\gamma \omega}$ increases with a fall in $p$. Law enforcement becomes more costly which reduces the demand for $z$ for a given $e$. The upward sloping ZZ curve shifts right. As is clear from the Figure 2 below, $e^{*}$ increases in the developing country. Since a fall in $p$ lowers $\frac{w}{r}$ in the developed country $D$, the effect of trade liberalization on $e^{*}$ is exactly opposite in the developed country $D$.

\footnotetext{
${ }^{6}$ Even if $Z Z$ is downward sloping our arguments hold as long as $Z Z$ is steeper than $E E$.
} 
(Figure 2 about here)

The ranking assumed above is not the only possible or the only plausible one. Also, the assumed ranking is not necessary to get the results; e.g., $e^{*}$ could be higher in the developing country $G$ even if $k_{e}^{G}<k^{G}$. Thus the effect of trade liberalization on expropriation is in general ambiguous and effectively an empirical question. Nonetheless, our theoretical framework helps in identifying the channels through which trade liberalization affects expropriation. More importantly, it highlights the possibility for sign reversals between developed and developing economies which finds support in the empirics.

\section{Data}

Illegal expropriation covers many activities from smuggling, coercion, through to violence, homicide and civil wars. To take the theory to the data we consider one well defined element of expropriation for which comparable data is available across countries, specifically theft and burglaries. Our primary data source is the official crime data, as reported to the authorities, from the United Nations Survey of Crime Trends and Operation of Criminal Justice (UNCS). This data-set offers a time span of nearly four decades (1970-2008) and covers 156 countries.

Despite the relative consistency of this data, it is nevertheless recognized that official crime data, like the UNCS, tend to suffer from under-reporting. Official data are likely to be particularly biased if there is a lack of trust in the authorities (Fajnzylber et al. 2000), or if there is corruption within the judicial system (Bourguignon 1999). ${ }^{7}$

Hence the reporting rate is not expected to be constant across countries, nor across time, but will depend on the country's changing characteristics (Gibson and Kim 2008). As the reporting rate does not vary randomly across countries, ignoring this issue would result in biased estimates.

A solution to this is to use victimization data, as reported in households surveys, a more

\footnotetext{
${ }^{7} \mathrm{~A}$ second problem is that some countries have modified their classification of crime over time (Mosher, Miethe and Hart 2011, Zvekic and Alvazzi del Frate 1995). Following Fajnzylber et al. (2000), the data was scanned for such inconsistencies and observations that were clearly out of line, without a plausible explanation, have been dropped. Given the arbitrary nature of this correction, all the models discussed in this paper have been estimated using the corrected version of the data (results presented in this paper) and using the original version of the data (results available on request). Both versions lead to similar conclusions. A related problem is the inclusion of burglaries and automobile theft in the UNCS definition of theft for some years but their separate recording in others. To ensure consistency our variable thefts is inclusive of automobile theft, burglaries and other thefts. Finally, 5 year averages are taken so as to smooth any large jumps in the data that might be caused by misreporting for a given year.
} 
accurate and consistent measure of crime rates across countries (Soares 2004). Such data is, however, less widely available.

An alternative solution is to 'correct' the official crime data using an estimated reporting rate by calculating the reporting rate error, rrate. Specifically, following Soares (2004), let $Y^{*}$ be the $\log$ of the true crime rate and $Y$ be the log of the official reported crime rate, $Y$. Then the $\log$ of the reporting rate error is defined as $\ln ($ rrate $)=Y-Y^{*}$.

Now suppose that $Y^{*}$ is explained by the model

$$
Y^{*}=X \theta+\varepsilon
$$

where $X$ is a matrix of country characteristics explaining the crime rate and $\varepsilon$ is an independent and identically distributed error term. ${ }^{8}$

Then if we estimate the crime rate using the officially reported crime rate data, $Y$, and if the reporting rate varies across countries in a non random way, we will have

$$
Y=X \theta+\varepsilon+\varphi
$$

where $\varphi \equiv \ln ($ rrate $)$ is the error resulting from misreporting. Assuming $\operatorname{COV}(\varphi \mid X) \neq 0$ then (9) will result in biased estimates for $\theta$.

If, however, we believe that the victimization data report the true crime rate, $Y^{*}$, then we can use this data to identify $\varphi=Y-Y^{*}$ for each country-year in which official crime data and victimization data are available. Assuming further that the relation between $\varphi$ and $X$ is constant over time and countries, and that $\varphi$ and $X$ are jointly normally distributed, we have

$$
E(\phi \mid X)=X \gamma
$$

where $\gamma$ is a constant. We can then calculate an estimated true crime rate $\widehat{Y}^{*}$ for all country-year observations for which we have data on the reported official crime rate and the country's characteristics. ${ }^{9}$

\footnotetext{
${ }^{8}$ As discussed below in Section 4, the matrix of country characteristics we use is taken from Soares (2004) and we include additional variables as well. The list of variables is given in Table 2 and defined in Table A1. Further details are given below in Section 4 when discussing the empirical reporting rate model, equation (11).

${ }^{9}$ Due to the presence of the corrected crime rate, the standard errors estimated by the OLS procedure are biased. This however, affects only the variable used in the reporting rate model. For further discussion see Glaeser and Sacerdote (1999) and Soares (2004). A simpler way of correcting for non-random differences in reporting rate across countries is to include country fixed effects as done by Fajnzylber et
} 
Thus we consider a reporting rate regression to obtain estimates of the extent of underreporting of crime to the authorities. Specifically, we use the UNCS in conjunction with the International Crime Victims Survey (ICVS). This latter data-set covers 46 countries over the period 1989 and 2005. ${ }^{10}$ The UNCS and the ICVS data overlap 107 times over the period 1985-2008. Once the necessary explanatory variables are included, we are left with a maximum overlap of 65 observations.

\subsection{Reporting Rate Results}

The reporting rate, rrate varies strongly across countries, from less than $1 \%$ to over $100 \%$ with an average of $8 \%$ and $15 \%$ for thefts and burglaries respectively. ${ }^{11}$

In Table 2, we present the results for Soares (2004) model for both thefts' and burglaries' $\log$ of the reporting rate using OLS. ${ }^{12}$ In columns 1 and 2, for thefts, and columns 4 and 5 , for burglaries, we replicate Soares (2004) specifications. We conclude, as Soares (2004) does, that among this set of explanatory variables, only GDP per capita is consistently statistically significant.

There are however other potentially important explanatory variables not taken into account by Soares (2004) such as the quality of institutions, as suggested by Kaufmann, Kraay and Zoido (1999) and ethnic fractionalization, a variable often associated with crimes and conflicts (Fafchamps and Moser 2003). We therefore consider including these variables as determinants of the reporting rate. We also include dummy variables for the major geographical areas, namely, Asia (asia), Latin America (latin) and Sub-Saharan

al. (2000). However, this technique will work only if the reporting rate is constant across time within each country. This is unlikely to hold in long panels. Using country-year fixed effects would resolve this issue in principle. However, as we have only one observation per country-period, we cannot include country-year fixed effects.

${ }^{10}$ To compare the ICVS data to the UNCS data, we define thefts as inclusive of car theft, theft from a car, theft of a motorcycle, bicycle theft and theft of personal property, while burglaries includes burglaries and theft from garages/sheds/lockups.

${ }^{11}$ As the victimization and the reported crime data come from different sources, the definition of thefts and burglaries do not match perfectly between the two database. This results in the reporting rate, rrate exceeding $100 \%$ for in a few instances in the burglaries data. To limit the extent of this problem, we followed Soares (2004) suggestions to harmonize the definitions of the variables, though small discrepancies may remain. The descriptive statistics summary for $\ln$ rrate are given in Table 1.

${ }^{12}$ In all models, the standard errors are adjusted for clustering at the country level. The countries included in the sample are listed in Appendix B. 
Africa $(S S A)$. Hence we estimate

$$
\begin{aligned}
\ln \left(\text { rrate }_{i t}=\right. & \alpha_{0}+\alpha_{1} g d p_{i t}+\alpha_{2} \text { democ }_{i}+\alpha_{3} \text { ethnic }_{i} \\
& +\alpha_{4} \text { asia }_{i}+\alpha_{5} \text { latin }_{i}+\alpha_{6} S S A_{i}+\nu_{i t}
\end{aligned}
$$

where $g d p$ is the log of per capita gross domestic product taken from the Penn World Tables, democ is a dummy variable taking the value of one if the country has been a democracy for the whole period for which the data is available and zero otherwise and ethnic is a measure of ethnic fractionalization taken from Alesina, Devleeschauwer, Easterly, Kurlat and Wacziarg (2003). Based on the adjusted R-squared we use this extended model (Columns 3 and 6) as our preferred specification. Thus, as in Soares (2004), we conclude that GDP per capita has a positive impact on the reporting rate. In the thefts' reporting rate model, we also conclude that a stable democracy increases the reporting rate while ethnic diversity reduces it. The results also show that the reporting rate for theft is significantly lower in Asia and Latin America and significantly higher in Sub-Saharan Africa.

Using the estimated reporting rates, we then proceed to correct the official reported thefts' and burglaries' crime rates. As expected, the officially reported crime rates vary more than the "true", or corrected, crime rates, as shown by their respective standard deviations (Table 1).

(Tables 1 and 2 about here)

\section{Crime and Trade Liberalization}

Having obtained corrected estimates of theft and burglary rates, we now turn to consider the relationship between trade liberalization and crime, where crime is measured by either theft or burglaries. Our theoretical model suggests that a change in trade policy regimes will have an impact on crime, but that the sign of this effect is ambiguous. In particular it depends on the sign of the Stolper-Samuelson effects which in turn depend on whether a country is labor or capital abundant. We consider the following model,

$$
\ln \left(\text { crime }_{i t}\right)=\beta_{0}+\beta_{1} k_{i}+\beta_{2} \text { trade }_{i t}+\beta_{3}\left(k_{i} \text { trade }_{i t}\right)+\gamma_{i} Z_{i, t}+\varepsilon_{i t}
$$

where crime is measured either as thefts per 100,000 inhabitants or as burglaries per 100,000 inhabitants, adjusted for the reporting rate; trade is an indicator of the openness, 
or restrictiveness, of the trade regime; and $k$ is the log of the ratio of capital per worker in 1970 to the average world capital per worker for the same year, and $Z_{i, t}$ is a vector of additional explanatory variables. As high theft and burglary rates may impede capital accumulation, leading the variable capital per labor to be endogenous, we use the capital per labor ratio prevalent in 1970, 10 years before our first observation. ${ }^{13}$

The key feature of (12) is the interaction between the log capital-labor ratio, $k$, and trade. ${ }^{14}$ If a country's capital per worker is equal to the world average then $k_{i}=0$. Hence $\beta_{2}$ gives the impact of trade on the country with average capital abundance. Note that this may well be zero according to the theory. For countries with $k_{i}$ above or below the world average, $k$, the impact of trade on the crime rate is $\partial$ crime $/ \partial t r a d e=\beta_{2}+\beta_{3} k$.

To measure the trade regime, trade, we use two indices. The first is the widely used 'openness' measure - the log of the ratio of trade over GDP (open). The second is the log of the ratio of duties over imports (duties). ${ }^{15}$ The additional control variables include all the variables in the reporting rate regression (log of GDP per capita, stable democracy, ethnic fractionalization and the regional dummy variables) as well as: the growth rate of GDP per capita ( $g d p g)$; population size and population size squared ( $p o p$ and pop2); and, the unemployment rate (unemp). Further details of the data sources are given in Appendix $\mathrm{C}$ and descriptive statistics are presented in Table 1.

\subsection{Base Model Estimation}

For our base model we simply use a pooled clustered sandwich estimator to adjust for time series correlation in the error terms within each country. The results from this base model are presented in Table 3 (Column 1). ${ }^{16}$

First note that the coefficient of open is insignificantly different from zero. As noted above this implies that open has no impact on theft for countries with average capital abundance, which is consistent with our theory. Examples of such countries are Costa

\footnotetext{
${ }^{13}$ As a robustness check we have used the contemporaneous value of the capital per labor ratio. The main conclusions remain the same and are available on request.

${ }^{14}$ This follows for example similar specifications used by Dutt et al. (2009) and Dutt and Mitra (2002) in their empirical models of unemployment and protection.

${ }^{15}$ The ratio of trade over GDP is from the World Bank (2009) while the ratio of duties over imports is from the WDI and the Historical Government Finance Statistics (International Monetary Fund 2005).

${ }^{16}$ While only the main variables of interest are presented in the core of this paper, the results for the control variables are available in Appendix D. As a robustness check, the same model is estimated with the standard errors corrected for autocorrelation of order one. The results are similar. The only notable difference is the loss of statistical significance for the trade variable, as measured by duties, in the model explaining burglaries (results available on request).
} 
Rica, Morocco and Tunisia.

Next we note that that the impact of trade depends on the relative capital abundance, as indicated by the negative and statistically significant interaction term open $k$. Thus open is associated with an increase in the theft rate in labor abundant countries, and a decrease in the theft rate in capital abundant countries. Joint significance tests for the partial impact of trade, $\beta_{2}+\beta_{3} k$ are also presented for values of the log of the capital labor ratio, $k=-4, k=-2$ and $k=2$. As can be seen in Figure 4 , the values of -4 to 2 cover the sample distribution. Nevertheless it can also be seen that the distribution of $k$ is fairly even with significant numbers of observations at these end points.

From the results in Table 3 (Column 1) it can be seen that the total impact of openness is highly significant and negative for capital abundant countries, $k=2$, marginally insignificant at moderately low levels of labor abundance, $k=-2$, and highly significant and positive for high level of labor abundance, $k=-4$. Thus, in relatively capital abundant countries like Australia, Singapore and the United States, theft rates decrease following a trade liberalization policy, while the opposite is true for labor abundant countries like Uganda and Bangladesh.

A visual summary of this result is given in panel (i) of Figure 3. This shows the estimated line $\partial$ crime $/ \partial$ trade $=\beta_{2}+\beta_{3} k$. The dotted lines shows the $90 \%$ and $95 \%$ confidence intervals for all values of $k$, around the estimated line. From this figure we note that over the sample range for $k$, the elasticity dcrime/Dtrade varies from approximately unity for the most labor abundant countries to approximately -0.5 for the most capital abundant countries. Nevertheless it can also be seen that for a large range of countries, from approximately $k=-3$ to $k=1$, the impact of openness on crime is statistically insignificant. Moreover as can be seen in Figure 4, this range of capital labor ratio accounts for $71 \%$ of the countries for which the data exists in the Penn World Tables.

Hence the results suggest that, for most country/time observations, increasing openness is unlikely to have any effect on theft. Nevertheless they also show that, for the most labor abundant countries, openness tends to increase crime. Likewise, for the most capital abundant countries, openness reduces crime. In terms of our theoretical model this result is consistent with a scenario where crime prevention or law enforcement is a relatively labor abundant activity in both developed and developing economies.

Figures 3 and 4 about here 


\subsection{Base Model Estimation for Alternative Variables}

Thus far we have considered the result for estimating (12) using thefts as the dependent variable and open as a measure of the trade policy regime. In addition we wish to consider the model using data on burglaries as a dependent variable and duties as an alternative measure of trade restrictiveness. This gives four different applications of equation (12). The results for each of these additional implementations of (12) are given in column 1 of Tables 4 to 6 . These results are summarized in the remaining panels of Figure 3.

First consider using the rate of duties relative to imports (duties) as an alternative measure of trade restrictiveness. Arguably this variable is a more reliable measure of trade policy than openness. The cost, however, is a drop in the sample size from 240 to 155 observations as the variable duties is only available since 1990. Panel (ii) of Figure 3 shows that when we use duties, we obtain very similar results as the ones previously discussed. As duties is a measure of trade restrictiveness the upward slope of the curve in panel (ii) is consistent with the downward slope in panel (i). In this case, a $1 \%$ increase in duties is shown to decrease crime in the most labor abundant countries $(k=4)$ by $0.6 \%$. This effect becomes insignificant at the $5 \%$ level for countries in the range $k=0$ and above. Hence, in this case, we do not find that higher levels of duties significantly reduce crime in the most developed countries, but the range of labor abundant countries where trade policy does affect crime is widened. Broadly speaking however the results are quite similar to the previous results in panel (i).

Next we consider the effect of trade on burglaries. A potential advantage of using data on burglaries, which is defined as theft associated with breaking and entering a premise, is that it is a more narrowly concept than theft and, hence, may be more consistently defined across countries. This variable is however available for a shorter span of time, 1986-2008.

With open as the index of trade openness it can be seen, in Figure 3, panel (iii), that the results are quite similar to the preceding thefts model in panel (i). Again there is a sign reversal and the range of medium levels of $k$ where the impact of crime is insignificant is now reduced. Openness increases burglaries for values of approximately $k<-1$, and reduces burglaries for countries with $k>1$. Moreover the estimated elasticities at the extremes are now much larger, ranging from approximately 3 to -1.5 .

The results from estimating (12) for burglaries when duties is the trade restrictiveness variable are reported in panel (iv) of Figure 3. It can be seen that these results are again very similar to the preceding result for thefts and duties in panel (ii). Again the 
estimated range of elasticities is somewhat larger than when the theft data are used, and the impact of duties on burglaries is just significant at the $10 \%$ level for $k=2$, whereas it was insignificant in the thefts-duties case reported in panel (ii). There is a relatively large range of values of $k$ where dcrime/dtrade is insignificant, though in this case the sample size is the smallest of all four cases.

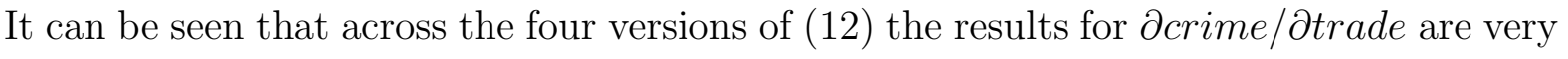
consistent. They suggest that a more liberal trade regime is associated with higher crime rates in labor abundant countries and that this effect declines and may reverse sign as we consider more capital abundant counties. All models suggest larger coefficients for labor abundant countries, with smaller or possibly insignificant impacts for capital abundant countries. $^{17}$

(Figure 3 about here)

\subsection{Economic Significance}

Finally note that, according to these results, the estimated impact of trade liberalization on crime is economically significant, though this depends very much on the individual country characteristics - specifically whether capital or labor abundant a country is relative to the world average and whether trade liberalization increased or decreased.

By way of illustration, Table 7 reports the implied change in thefts for a selection of countries. Specifically it reports the results for countries where the predicted impact is significantly different from zero, and where we have enough panel data to compare the predicted change with the actual change over the same period. ${ }^{18}$

It can be seen that for most countries thefts declined over time. Thus for some labor

\footnotetext{
${ }^{17}$ Alcala and Ciccone (2004) propose the use of "real openness", defined as the ratio of imports and exports to PPP GDP for looking at the effects of productivity growth in the export sector on GDP growth. This is because, with a non-tradable sector, a rising price of non-tradables may cause openness to decline, since the value of non-tradables - which appears in the numerator - rises relative to tradables. In this paper, however, we are not using openness as a measure of productivity in the export sector, but simply as a measure of the level of protection. In a standard trade model with two goods, it is straightforward to show that a tariff ridden equilibrium will always have a lower level of openness than the free trade equilibrium, since it reduces the value of exports and imports and raises national income valued at domestic prices - due to the tariff revenue effect. Hence, for our purposes, the standard openness measure is appropriate. If we do use real openness, however, the results remain unchanged for the burglaries model and there is some small loss of significance for the thefts model, though the interaction term remains significant at the 10 percent level. These results are also available on request.

${ }^{18}$ For the purpose of this table we report all countries where the predicted effect, which depends on the country's capital abundance, is significant at the $10 \%$ level.
} 
abundant countries the effect of trade liberalization was opposite to the overall change in crime. The magnitude of the predicted effect, however, suggests that the decline in crime for some of these countries, such as Thailand, Bangladesh, and China, might have been 50 to $100 \%$ larger in the absence of the increase in openness. Conversely for Pakistan, Indonesia, and Egypt where openness declined, it can been seen that our model predicts that a significant part of the net decline in thefts was due to trade.

Likewise for Switzerland, which is a capital abundant country, we see that the increase in openness accounts for around 16 percentage points of the 47 percent decline in crime. A similar pattern exists in the Netherlands. The predicted effects in Table 7 thus show that the overall effects of openness on thefts tend to be large, but not unreasonably so relative to the actual changes over time.

Table 8 provides similar evidence for the effects of openness on burglaries. Again, in some cases openness, is seen to be offsetting factor to the overall trend, while in a few countries, such as Pakistan, Botswana and Switzerland, the predicted impact potentially accounts for most of the observed change.

Of course in many more countries where labor abundance is closer to to the world average, the effects are insignificant. These tables show, however, than in cases where openness does have an impact on crime, the predicted size of the effects are economically significant and so are likely to be an important contributing or mitigating factor in understanding the overall change in theft or burglaries. ${ }^{19}$

\section{Robustness}

\subsection{Crime and inequality}

A natural question is whether our our results are consistent with the crime literature that tend to emphasis inequality. For example Imrohoroglu et al. (2004) find that rising inequality in the USA has prevented what would have otherwise been a very large decrease in crime. In our model inequality is endogenous - a change in commodity prices affects both factor returns and the level of expropriation. Hence crime and inequality are correlated but there is no causal link between inequality and crime.

Nevertheless other factors can also affect inequality, and there may be other links between

\footnotetext{
${ }^{19}$ Likewise the results for the quantitative impact of duties on crime give results that are economically significant and within reasonable bounds. These additional results are available upon request.
} 
inequality and crime example, according to Fajnzylber, Lederman and Loayza (2002), inequality generates resentment, leading the poor to seek compensation through crime. Following Fajnzylber et al. (2002), we therefore control for inequality by including either the Gini coefficient, gini, or the ratio of the income earned by the $20 \%$ richest on the income earned by the $20 \%$ poorest, henceforth ratio. Due to limited data availability we use the average gini and the average ratio overall years for which the data have been collected.

As shown in Tables 3 to 6 (Columns 2 and 3) these two measures of inequality never reach statistical significance at the $5 \%$ level or lower. Moreover the inclusion of an inequality measure in the model does not change our main conclusion that an increase in trade openness leads to an increase in crime in labor abundant countries and a decrease in crime in capital abundant countries.

\subsection{Institutional Differences}

A second potential concern is that institutional differences across countries will affect the impact of trade on crime. In particular democratic countries may offer social protection to those who lose from increasing trade or may allow discontents to be heard in the public sphere. Democracy is already included in our preceding models, as well as the reporting rate regression. Nevertheless this argument suggests an interaction between democracy and changes in the trade regime. ${ }^{20}$ To test for this we include the multiplicative variable democ $_{i} \times$ trade $_{i t}$ into the model.

It can be seen in Column 4 of Tables 3 to 6 that this new variable democ $_{i} \times$ trade $_{i t}$ also never reaches statistical significance. Moreover, we conclude that the total impact of trade openness on crime is similar in democratic countries $\left(\beta_{2}+\beta_{3} k+\beta_{5}\right)$ and autocratic countries $\left(\beta_{2}+\beta_{3} k\right)$. The inclusion of this term, however, leads to important loss in statistical significance while not adding much to the model.

More generally we can consider a fixed effects (FE) estimator to hold constant any uncontrolled for determinants of crime across countries. The results for such models are presented in Column 5 of Tables 3 to 6 . As before we conclude that trade liberalization increases thefts in labor abundant countries but has the opposite effect in capital abundant countries. With respect to burglaries however there is now a lack of significance. Despite this however there is still considerable support for the model when using thefts

\footnotetext{
${ }^{20}$ In particular Besley and Persson (2008) find that the impact of commodity prices on conflict varies with whether or not a country is a democracy.
} 
data. $^{21}$

\section{Endogeneity}

\subsection{Endogeneity of trade policy variables}

Clearly endogeneity is important consideration that we have not so far discussed. The trade policy variables openness and duties may be endogenous and we cannot dismiss the possibility, for example, that high crime levels deter trade. Hence in this Section we use a generalized method of moments instrumental-variables (GMM-IV) model to instrument for open and duties.

Specifically, we instrument for openness using two variables: lagged openness and natural openness, where natural openness is the predicted openness, based solely on the geographic and historical characteristics of a country. Following Wei (2000) and Elbadawi and Hegre (2008), we estimate a model explaining the ratio of trade over GDP using, as explanatory variables: a measure of remoteness, the log of the population size, if the country is landlocked, the ratio of the coastline on the total area of the country, if the country is an island, if English is an official language, if French is an official language and if Spanish is an official language. Using this model, we predict the natural openness of the country, that is, the expected ratio of trade over GDP based solely on the geographic and the historical characteristics of the country. In contrast to the observed ratio of trade over GDP, natural openness is not expected to be influenced by the actual crime rate. Similarly we instrument for duties using its lagged value.

The results are reported in Column 6 of Tables 3 to 6 . For all models, we conclude that the first stage fit is high and that there is always at least one instrument reaching statistical significance in the first stage model. ${ }^{22}$ For open, as the model is over-identified, we also perform a test of over-identifying restriction and conclude that the set of instrument variables is valid. With the Shea partially adjusted R-squared of over 0.3 for all models,

\footnotetext{
${ }^{21}$ We report the results for a $\mathrm{FE}$ estimation with $\mathrm{AR}(1)$ errors rather than clustered errors. The thefts model performs slightly better with AR(1) errors though the burglaries model performs slights better with clustering.

${ }^{22}$ As noted by Cameron and Trivedi (2007), the IV estimator may approach the OLS estimator and therefore have a similar bias when the first stage fit is high and the number of instruments is very large relative to the sample size. Therefore, as a robustness check we have estimated the IV model with only the lag of the endogenous variables. We again conclude that there is no need to instrument. These results are available on request.
} 
we are also confident that our instruments are not weak (Shea 1997). ${ }^{23}$

Nevertheless we also note that, despite the strength of our instrumental variables, we find no strong evidence for the need for instruments. The Hausman tests show that open and open $\times k$ are not endogenous in the thefts' and the burglaries' models. The evidence is weaker for the duties-theft model as the Hausman test is only marginally insignificant. In any case, the GMM-IV estimator's results are similar to the OLS results found previously, reinforcing our confidence in our base model estimates.

\subsection{Endogeneity of crime rates}

A second endogeneity issue comes from the crime literature. Specifically past crime rates may affect the current crime rate, since a high crime rate is argued to weaken social capital (Case and Katz 1991), lower the psychological cost of committing crimes (Rasmusen 1996) and deter job creation in the legal sector (Glaeser, Sacerdote and Scheinkman 1996). These could all potentially lead to a higher crime rate in the future. Moreover, a surge in crime rates may overwhelm the law-enforcement services, thus decreasing the risk of apprehension, thus inducing further crime (Sah 1991).

In order to control for the past crime rate, we use an Arellano and Bond (AB) estimator (Arellano and Bond 1991). ${ }^{24}$ The results are given in Column 7 of Tables 3 and 4 (thefts) and Column 7 of Tables 5 and 6 (burglaries). Given the unbalanced structure of our panel, the use of past values of crime rate as explanatory variable leads to a sharp drop in the sample size even though we include only one lag. Nonetheless, despite the limited degrees of freedom, we conclude that more openness and less duties increase theft and burglary rates in labor abundant countries but have positive or no significant impact on capital abundant countries. Interestingly, once other factors are controlled for, past theft and burglary rates are not found to be statistically significant.

\footnotetext{
${ }^{23}$ Again these additional results are available upon request. We do not perform the Stock and Yogo (2002) tests as we cannot assume that our standard errors are iid.

${ }^{24}$ The $\mathrm{AB}$ estimator is similar to the first difference estimator in the sense that the variation in the dependent variable is explained by the variation in the explanatory variables. Among those explanatory variables is the past crime rate. By definition, the variation in lag_crime is correlated with $\varepsilon$. Arellano and Bond's solution to this problem is to use the past level values of the dependent variable as instruments.
} 


\section{Conclusion}

The social costs of trade liberalization are at the core of the debate over the broader effects of globalization. Contributions such as Rodrik (1997) have given some legitimacy to skeptics' concerns about the social costs of trade reforms. Likewise Findlay and O'Rourke (2007) and Williamson (2011) warn that one cannot assume that the path of globalization will follow a benevolent trend. Other contributions to the debate such as Bhagwati (2004) and Wolf (2004) also point to the many complex and varied effects of globalization, but also denounce what they suggest are false alarms from populist media.

Against this background we consider how costly law enforcement and imperfect property rights modify the standard gain-from-trade propositions. We first outline a theoretical model that follows the recent literature on trade and expropriation, particularly Ghosh and Robertson (2012) and Dal Bo and Dal Bo (2011). The model shows that the effects of trade liberalization on expropriation activities, such as crime: (i) are ambiguous, and; (ii) differ across countries depending on the sign of the Stolper-Samuelson effects, and hence on a country's endowments of capital and labor.

We then test this theory using an unbalanced cross-country panel data set of theft and burglary rates. Across a range of specifications, including different measures of openness, we find substantial evidence in support of that proposition that trade liberalization can have a large effect on crime rates, and that trade liberalization increases crime rates in labor abundant countries, and reduces crime, or has no effect, in capital abundant countries. Moreover we find that the results are robust when we allow for endogeneity. Specifically we find that GMM-IV results are similar to our OLS results and we find little evidence of endogeneity of the trade policy variables. Likewise we find no evidence that current crime rates are affected by past crime rates once other explanatory variables are controlled for.

The results are consistent with a model where law-enforcement activities are labor intensive relative to crime activities. They offer some support for globalization sceptics, and suggest very large effects, especially for the most labor abundant countries. But they also suggest that for the majority of countries, there is either an insignificant or negative relationship between trade liberalization and crime. 


\section{Appendix A: Derivation of (5)}

An individual $i$ 's income comes from two sources: productive activities and expropriation. Consider first the income from expropriation. If $i$ succeeds in targeting $k$ and is not detected/convicted by legal authorities then she earns $\gamma \omega^{k}$. The probabilities of $i$ 's success in targeting $k$ and failure of detection/verification by courts are given by $\phi\left(e^{i}\right)$ and $1-\alpha\left(z^{k}\right)$ respectively. As these two events are independent, the probability that $i$ successfully expropriates $\gamma \omega^{k}$ from $k$ is $\phi\left(e^{i}\right)\left(1-\alpha\left(z^{k}\right)\right)$. Since individual $i$ earns zero in all other cases, an individual $i$ 's income from expropriation is

$$
\begin{aligned}
& \gamma \omega^{k}, \quad \text { with probability } \phi\left(e^{i}\right)\left(1-\alpha\left(z^{k}\right)\right) \text {; } \\
& 0, \quad \text { with probability } 1-\phi\left(e^{i}\right)\left(1-\alpha\left(z^{k}\right)\right) \text {. }
\end{aligned}
$$

Now consider $i$ 's income from productive activities. Given that a fraction $\gamma \omega^{i}$ can be successfully expropriated by $j$ with probability $\phi\left(e^{j}\right)\left(1-\alpha\left(z^{i}\right)\right), i$ 's income from productive activities is

$$
\begin{aligned}
(1-\gamma) \omega^{i}, & \text { with probability } \phi\left(e^{j}\right)\left(1-\alpha\left(z^{i}\right)\right) ; \\
\omega^{i}, & \text { with probability } 1-\phi\left(e^{j}\right)\left(1-\alpha\left(z^{i}\right)\right) .
\end{aligned}
$$

Taking these different types of incomes and probabilities into account, and deducting the expenditures on legal services $p_{z} z^{i}$, individual $i$ 's expected overall income turns out as in equation (5) in the text:

$$
\bar{y}_{d}^{i}=\omega^{i}\left(1-\gamma \phi\left(e^{j}\right)\left(1-\alpha\left(z^{i}\right)\right)\right)+\gamma \omega^{k} \phi\left(e^{i}\right)\left(1-\alpha\left(z^{k}\right)\right)-p_{z} z^{i}
$$

\section{Appendix B: Countries Included in the Sample}

Reporting rate models: The countries for which the data overlap and for which we have all useful variables are: Argentina (only thefts), Australia, Austria, Belgium (only burglaries), Canada, China, Colombia, Costa Rica, Denmark, Egypt (only burglaries), Finland, France, Greece (only burglaries), Iceland, India, Indonesia, Ireland, Italy (only thefts), Japan, Luxembourg, Mexico, Netherlands, New Zealand, Norway, Panama (only thefts), Philippines (only thefts), Portugal, Romania, South Africa, South Korea, Spain, Sweden, Switzerland (only burglaries), Turkey, Uganda, United Kingdom, United States, Zambia and Zimbabwe.

Crime rate models: Algeria, Argentina (only thefts), Australia, Austria, Bangladesh, Barbados, Belgium, Bolivia, Botswana, Canada, Chile, China, Colombia, Costa Rica, 
Cyprus, Denmark, Ecuador, Egypt, El Salvador, Ethiopia (only burglaries), Fiji, Finland, France, Greece, Iceland, India, Indonesia, Iran (only thefts), Ireland, Israel, Italy, Jamaica, Japan, Jordan, Korea South, Lesotho (only burglaries), Luxembourg, Malawi (only thefts), Malaysia, Mauritius, Mexico, Morocco, Nepal (only thefts), Netherlands, New Zealand, Nicaragua, Norway, Pakistan, Panama (only thefts), Papua New Guinea, Paraguay, Peru, Philippines (only thefts), Portugal, Romania, Seychelles, Singapore, South Africa, Spain, Sri Lanka, Sweden, Switzerland, Syria, Thailand, Trinidad (only thefts), Tunisia, Turkey, Uganda, United Kingdom, United States, Uruguay, Venezuela (only thefts), Zambia and Zimbabwe.

\section{Appendix C: Definition of Variables}

(Table A.1 about here)

\section{Appendix D:}

(Table A.2 about here) 


\section{References}

Alcala, Francisco, and Antonio Ciccone (2004) 'Trade and productivity.' Quarterly Journal of Economics 119(2), 613-646

Alesina, Alberto, Arnaud Devleeschauwer, William Easterly, Sergio Kurlat, and Romain Wacziarg (2003) 'Fractionalization.' Journal of Economic Growth 8(2), 155-194

Anderson, James E., and Douglas Marcouiller (2005) 'Anarchy and autarky: Endogenous predation as a barrier to trade.' International Economic Review 46(1), 189-213

Anderson, James E., and Oriana Bandiera (2006) 'Traders, cops and robbers.' Journal of International Economics 70(1), 197-215

Arellano, Manuel, and Stephen Bond (1991) 'Some tests of specification for panel data: Monte Carlo evidence and an application to employment equations.' The Review of Economic Studies 58(2), 277-297

Becker, Gary S. (1968) 'Crime and punishment: An economic approach.' The Journal of Political Economy 76(2), 169-217

Besley, Timothy J., and Torsten Persson (2008) 'The incidence of civil war: Theory and evidence.' NBER Working Paper Series, 14585

Bhagwati, Jagdish. (2004) In Defense of Globalization (N.Y.: Oxford University Press)

Bourguignon, Francois (1999) 'Crime, violence and inequitable development.' Annual World Bank Conference on Development Economics. Washington D. C.

Bruckner, Markus, and Antonio Ciccone (2010) 'International commodity prices, growth and the outbreak of civil war in Sub-Saharan Africa.' The Economic Journal $120(544), 519-534$

Bushway, Shawn D., Philip J. Cook, and Matthew Phillips (2010) 'Youth crime and violence over the business cycle.' Unpublished Draft. Duke University

Cameron, A. Colin, and Pravin K. Trivedi (2007) Microeconometrics: Methods and Applications (Cambridge: Cambridge University Press)

Case, Anne C., and Lawrence F. Katz (1991) 'The company you keep: The effects of family and neighborhood on disadvantaged youths.' NBER Working Paper Series, 3705 
Collier, Paul, and Anke Hoeffler (2004) 'Greed and grievance in civil war.' Oxford Economic Papers 56(4), 563-595

Cook, Philip J. (2010) 'Property crime yes violence no.' Criminology and Public Policy $9(4), 693-697$

Dal Bo, Ernesto, and Pedro Dal Bo (2011) 'Workers, warriors, and criminals: Social conflict in general equilibrium.' Journal of European Economic Association 9(4), 646677

Deardorff, Alan V. (2000) 'Policy implications of the trade and wages debate.' Review of International Economics 8(3), 478-496

Demombynes, Gabriel, and Berk Ozler (2005) 'Crime and local inequality in South Africa.' Journal of Development Economics 76(2), 265-292

Dodson, Michael (2002) 'Review: Assessing judicial reform in Latin America.' Latin American Research Review 37(2), 200-220

Dube, Oeindrila, and Juan F. Vargas (2011) 'Commodity price shocks and civil conflict: Evidence from Colombia.' Mimeo, Harvard University

Dutt, Pushan, and Devashish Mitra (2002) 'Endogenous trade policy through majority voting: an empirical investigation.' Journal of International Economics 58(1), 107133

Dutt, Pushan, Devashish Mitra, and Priya Ranjan (2009) 'International trade and unemployment: Theory and cross-national evidence.' Journal of International Economics 78(1), 32-44

Ehrlich, Isaac (1973) 'Participation in illegitimate activities: A theoretical and empirical investigation.' The Journal of Political Economy 81(3), 521-565

Elbadawi, Ibrahim, and Havard Hegre (2008) 'Globalization, economic shocks, and internal armed conflict.' Defence and Peace Economics 19(1), 37-60

Fafchamps, Marcel, and Christine Moser (2003) 'Crime, isolation and law enforcement.' Journal of African Economies 12(4), 625-671

Fajnzylber, Pablo, Daniel Lederman, and Norman Loayza (2002) 'Inequality and violent crime.' Journal of Law and Economics 45(1), 1-39 
Fajnzylber, Pablo, Daniel Lederman, Norman Loayza, Peter Reuter, John Roman, and Alejandro Gaviria (2000) 'Crime and victimization: An economic perspective [with comments].' Economia 1(1), 219-302

Findlay, Ronald, and Kevin H. O'Rourke (2007) Power and Plenty: Trade, War, and the World Economy in the Second Millennium (Princeton University Press)

Ghosh, Arghya, and Peter E. Robertson (2012) 'Trade and expropriation.' Economic Theory 50(1), 169-191

Gibson, John, and Johnand Bonggeun Kim (2008) 'The effect of reporting errors on the cross-country relationship between inequality and crime.' Journal of Development Economics 87(2), 247 - 254

Glaeser, Edward L., and Bruce Sacerdote (1999) 'Why is there more crime in cities?' The Journal of Political Economy 107(6), S225-S258

Glaeser, Edward L., Bruce Sacerdote, and Jose A. Scheinkman (1996) 'Crime and social interactions.' The Quarterly Journal of Economics 111(2), 507-548

Imrohoroglu, Ayse, Antonio Merlo, and Peter Rupert (2000) 'On the political economy of income redistribution and crime.' International Economic Review 41(1), 1-25

_ (2004) 'What accounts for the decline in crime?' International Economic Review $45(3), 707-729$

International Monetary Fund (2005) 'Historical government finance statistics: 1972-1989 in Government Finance Statistics Manual 1986 format cd rom’

Irwin, Douglas (1996) Against the Tide: An Intellectual History of Free Trade (Princeton N.J.: Princeton University Press)

Kaufmann, Daniel, Aart Kraay, and Pablo Zoido (1999) 'Governance matters.' World Bank Policy Research Working Paper Series, 2196

Miguel, Edward, Shanker Satyanath, and Ernest Sergenti (2004) 'Economic shocks and civil conflict: An instrumental variables approach.' Journal of Political Economy $112(4), 725-753$

Mosher, Clayton J., Terrance D. Miethe, and Timothy C. Hart (2011) The Mismeasure of Crime, 2nd ed. (Thousand Oaks: SAGE Publication)

Pyle, D. J., and D. F. Deadman (1994) 'Crime and the business cycle in post-war Britain.' British Journal of Criminology 34(3), 339-357 
Rasmusen, Eric (1996) 'Stigma and self-fulfilling expectations of criminality.' Journal of Law and Economics 39(2), 519-543

Rodrik, Dani (1997) Has Globalization Gone too Far? (Washington DC: Institute for International Economics)

Sah, Raaj K. (1991) 'Social osmosis and patterns of crime.' The Journal of Political Economy 99(6), 1272-1295

Shea, John (1997) 'Instrument relevance in multivariate linear models: a simple measure.' The Review of Economics and Statistics 79(2), 348-352

Soares, Rodrigo R. (2004) 'Development, crime and punishment: Accounting for the international differences in crime rates.' Journal of Development Economics $73(1), 155-184$

Stock, J. H., and M. Yogo (2002) 'Testing for weak instruments in linear IV regression.' NBER Working Paper Series, 284

Wei, Shang-Jin (2000) 'Natural openness and good government.' NBER Working Paper Series, 7765

Williamson, Jeffrey G. (2011) Trade and Poverty: When the Third World Fell Behind (London England: MIT Press)

Wolf, Martin (2004) Why Globalization Works (New Haven: Yale University Press)

World Bank (2009) 'World Development Indicators cd rom.' Washington, D.C.: The World Bank, Development Data Group

Zvekic, Ugljesa, and Anna Alvazzi del Frate (1995) 'International crime (victim) survey in the developing world.' In Criminal Victimisation in the Developing World, ed. Ugljesa Zvekic and Anna Alvazzi del Frate (Rome: United Nations Interregional Crime and Justice Research Institute) pp. 3-14 


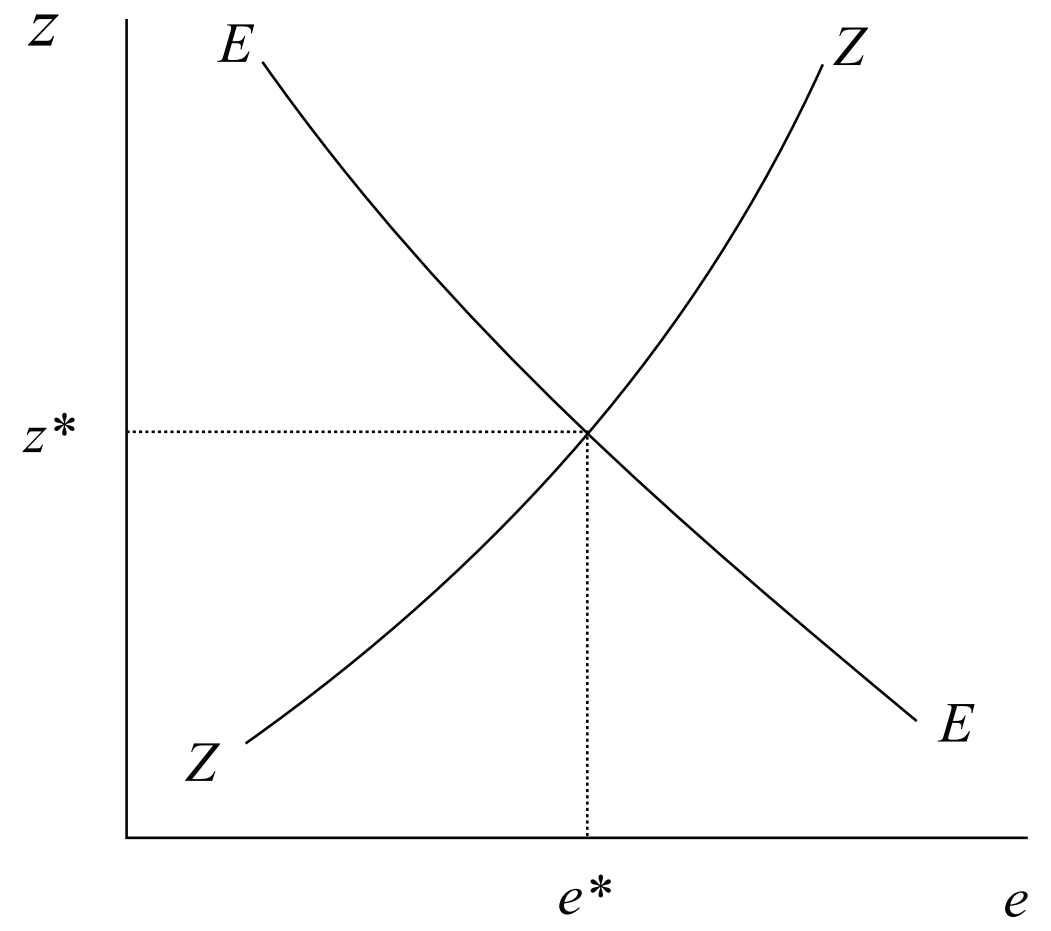

Figure 1: Equilibrium Determination of Expropriation and Law Enforcement 


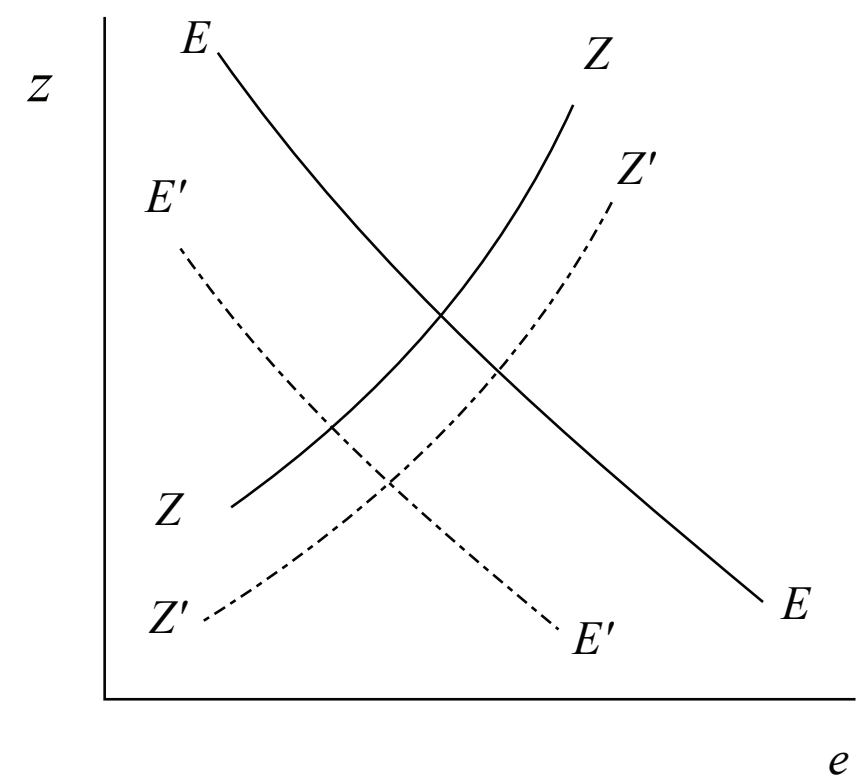

(i) Expropriation Falls

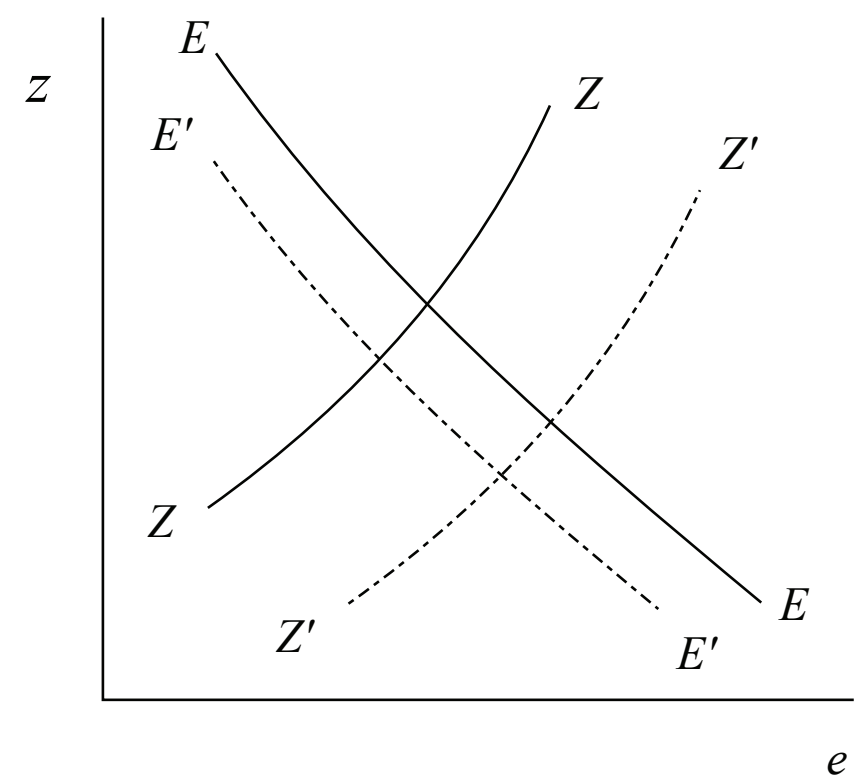

(ii) Expropriation Increases

Figure 2: The impact of Trade Liberalization on Expropriation 

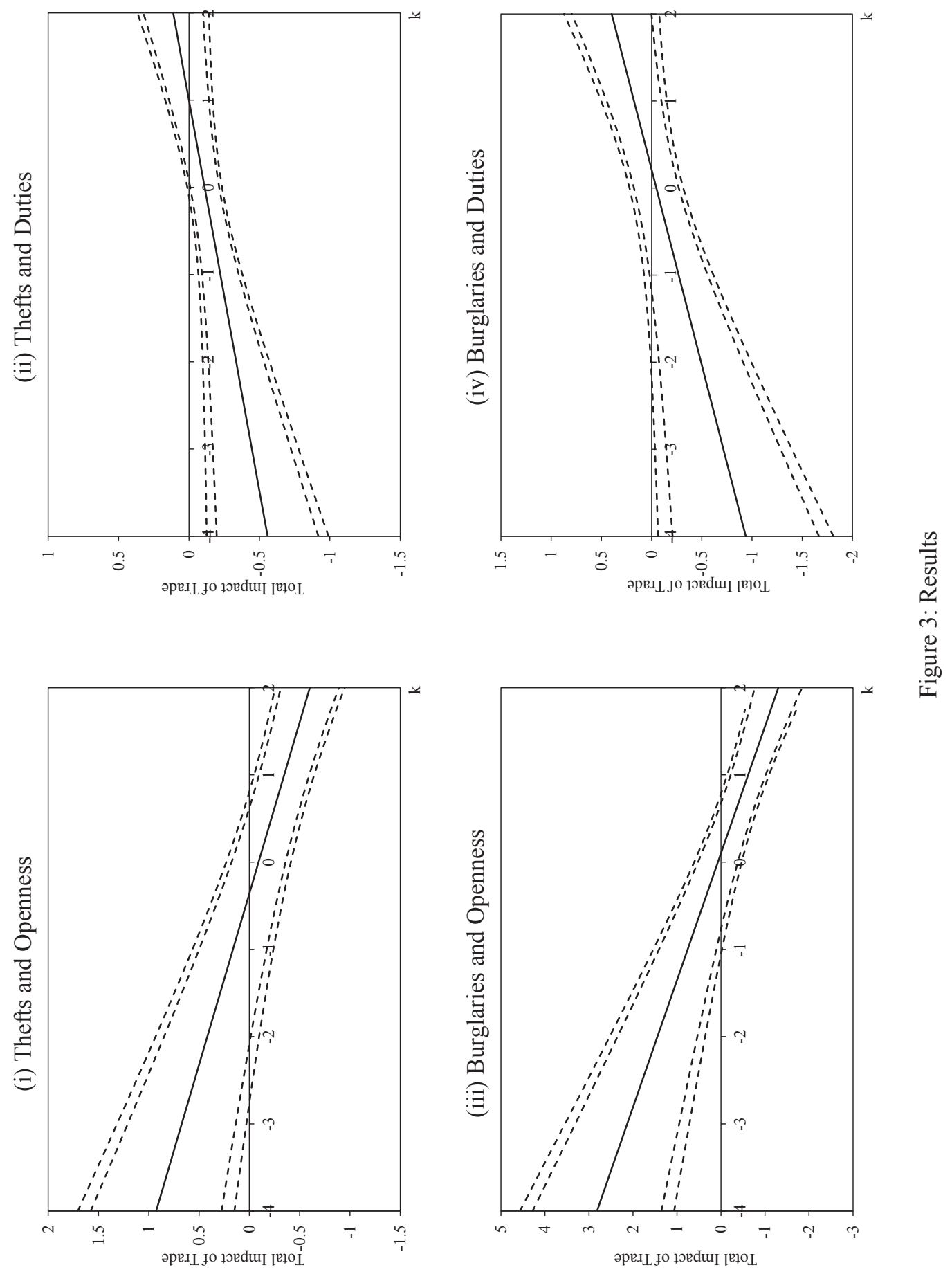


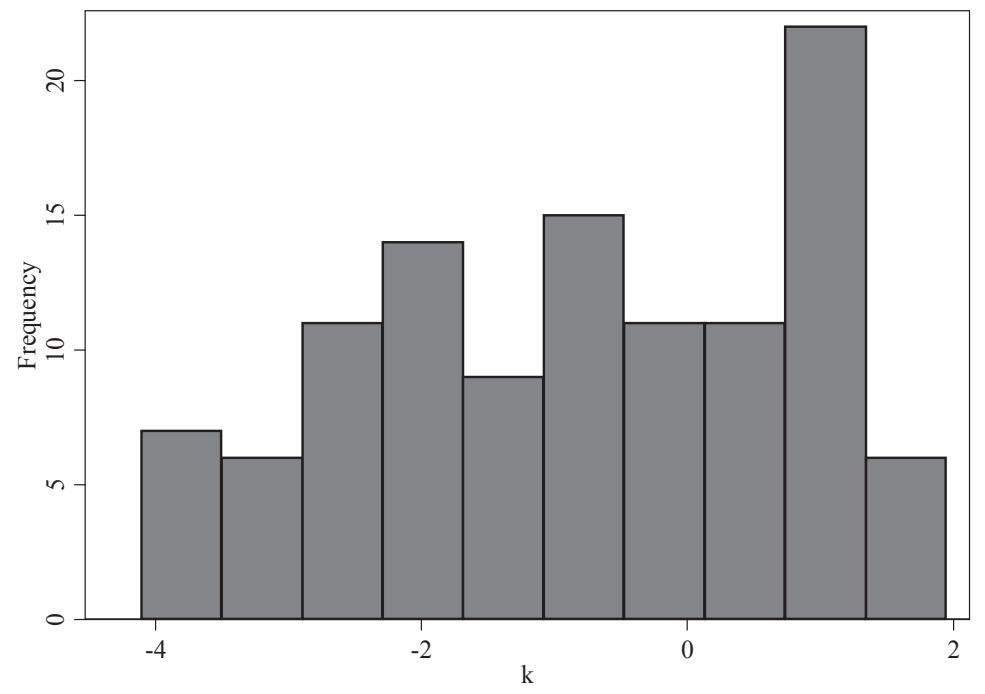

Figure 4: The World Distribution of $k$ 
Table 1: Descriptive Statistics

\begin{tabular}{|c|c|c|c|c|c|c|}
\hline Variable Name & Definition & Mean & Std. Dev. & Min & Max & Obs. \\
\hline log(rrate) (thefts) & Log of Reporting Rate (Thefts). & -2.57 & 1.55 & -6.34 & -1.00 & 65 \\
\hline log(rrate) (burglaries) & Log of Reporting Rate (Burglaries). & -1.88 & 1.78 & -7.06 & 0.98 & 63 \\
\hline thefts (original) & Log of Official Thefts Rate (Per 100,000 Inhabitants, Original). & 6.63 & 1.69 & 0.12 & 9.02 & 240 \\
\hline thefts (corrected) & Log of Official Thefts Rate (Per 100,000 Inhabitants, Corrected). & 9.98 & 0.90 & 5.35 & 12.53 & 240 \\
\hline burglaries (original) & Log of Official Burglaries Rate (Per 100,000 Inhabitants, Original). & 5.20 & 2.03 & -2.72 & 7.77 & 185 \\
\hline burglaries (corrected) & Log of Official Burglaries Rate (Per 100,000 Inhabitants, Corrected). & 7.84 & 1.41 & 1.94 & 10.03 & 185 \\
\hline$g d p$ & Log of Real GDP per Capita (2005, Constant International Dollars). & 9.33 & 0.94 & 6.90 & 11.22 & 240 \\
\hline democ & Democracy Dummy. & 0.45 & 0.50 & 0.00 & 1.00 & 240 \\
\hline ethnic & Index of Ethnic Fractionalization. & 0.32 & 0.23 & 0.00 & 0.93 & 240 \\
\hline asia & East and Southeast Asia Dummy. & 0.14 & 0.35 & 0.00 & 1.00 & 240 \\
\hline latin & Latin America Dummy. & 0.23 & 0.42 & 0.00 & 1.00 & 240 \\
\hline$S S A$ & Sub-saharan Africa Dummy. & 0.07 & 0.25 & 0.00 & 1.00 & 240 \\
\hline gdpg & Growth Rate of Real GDP per Capita (2005, Constant International Dollars). & 2.24 & 2.74 & -14.92 & 13.05 & 240 \\
\hline pop & Population (In Millions). & 54.42 & 158.12 & 0.07 & 1229.63 & 240 \\
\hline unemp & Unemployment Rate. & 8.03 & 5.17 & 1.23 & 34.60 & 240 \\
\hline$k$ & Ratio of Capital per Worker on World Average Capital per Worker in 1970. & 0.19 & 1.19 & -3.66 & 1.94 & 240 \\
\hline open & Log of Trade as Percentage of GDP. & 4.16 & 0.55 & 2.62 & 6.10 & 240 \\
\hline duties & Log of Duties as Percentage of GDP. & -3.95 & 1.42 & -9.87 & -0.81 & 155 \\
\hline
\end{tabular}


Table 2: Reporting Rate

\begin{tabular}{|c|c|c|c|c|c|c|}
\hline & \multicolumn{3}{|c|}{ Thefts } & \multicolumn{3}{|c|}{ Burglaries } \\
\hline & (1) & (2) & (3) & (4) & (5) & (6) \\
\hline$g d p$ & $\begin{array}{c}2.4173^{* * *} \\
(0.0001)\end{array}$ & $\begin{array}{c}1.4579^{* * *} \\
(0.0000)\end{array}$ & $\begin{array}{c}0.9448^{* * *} \\
(0.0000)\end{array}$ & $\begin{array}{l}1.7665^{* *} \\
(0.0270)\end{array}$ & $\begin{array}{c}1.4787^{* * *} \\
(0.0000)\end{array}$ & $\begin{array}{c}0.8314^{* *} \\
(0.0394)\end{array}$ \\
\hline educ & $\begin{array}{c}0.0099 \\
(0.7760)\end{array}$ & & & $\begin{array}{c}0.0665 \\
(0.1756)\end{array}$ & & \\
\hline urban & $\begin{array}{c}-0.0514^{*} \\
(0.0795)\end{array}$ & & & $\begin{array}{c}-0.0379 \\
(0.2029)\end{array}$ & & \\
\hline ratio & $\begin{array}{l}-0.0135 \\
(0.7652)\end{array}$ & & & $\begin{array}{c}-0.0929 \\
(0.1396)\end{array}$ & & \\
\hline christian & $\begin{array}{l}-0.1191 \\
(0.7978)\end{array}$ & & & $\begin{array}{l}0.9992^{*} \\
(0.0885)\end{array}$ & & \\
\hline police & $\begin{array}{c}0.2084 \\
(0.3668)\end{array}$ & & & $\begin{array}{c}0.4064 \\
(0.3244)\end{array}$ & & \\
\hline democ & & & $\begin{array}{c}0.7358^{* * *} \\
(0.0073)\end{array}$ & & & $\begin{array}{l}1.0456^{*} \\
(0.0610)\end{array}$ \\
\hline ethnic & & & $\begin{array}{c}-0.7282^{* *} \\
(0.0437)\end{array}$ & & & $\begin{array}{c}-0.4088 \\
(0.5083)\end{array}$ \\
\hline asia & & & $\begin{array}{c}-1.3393^{* * *} \\
(0.0026)\end{array}$ & & & $\begin{array}{l}-1.7817 \\
(0.1127)\end{array}$ \\
\hline latin & & & $\begin{array}{c}-1.2507 * * * \\
(0.0001)\end{array}$ & & & $\begin{array}{c}-1.3551^{* * *} \\
(0.0094)\end{array}$ \\
\hline$S S A$ & & & $\begin{array}{c}0.8664^{* *} \\
(0.0234)\end{array}$ & & & $\begin{array}{c}0.0577 \\
(0.9400)\end{array}$ \\
\hline Constant & $\begin{array}{c}-23.0298^{* * *} \\
(0.0002) \\
\end{array}$ & $\begin{array}{c}-16.7319^{* * *} \\
(0.0000) \\
\end{array}$ & $\begin{array}{c}-11.8390^{* * *} \\
(0.0000)\end{array}$ & $\begin{array}{c}-23.0012^{* * *} \\
(0.0010) \\
\end{array}$ & $\begin{array}{c}-16.3431^{* * *} \\
(0.0000) \\
\end{array}$ & $\begin{array}{c}-10.3727^{* * *} \\
(0.0093) \\
\end{array}$ \\
\hline Observations & 23 & 65 & 65 & 21 & 63 & 63 \\
\hline$R$-squared & 0.8002 & 0.7164 & 0.8972 & 0.7232 & 0.5587 & 0.6904 \\
\hline AdjustedR-squared & 0.725 & 0.712 & 0.887 & 0.605 & 0.551 & 0.657 \\
\hline
\end{tabular}




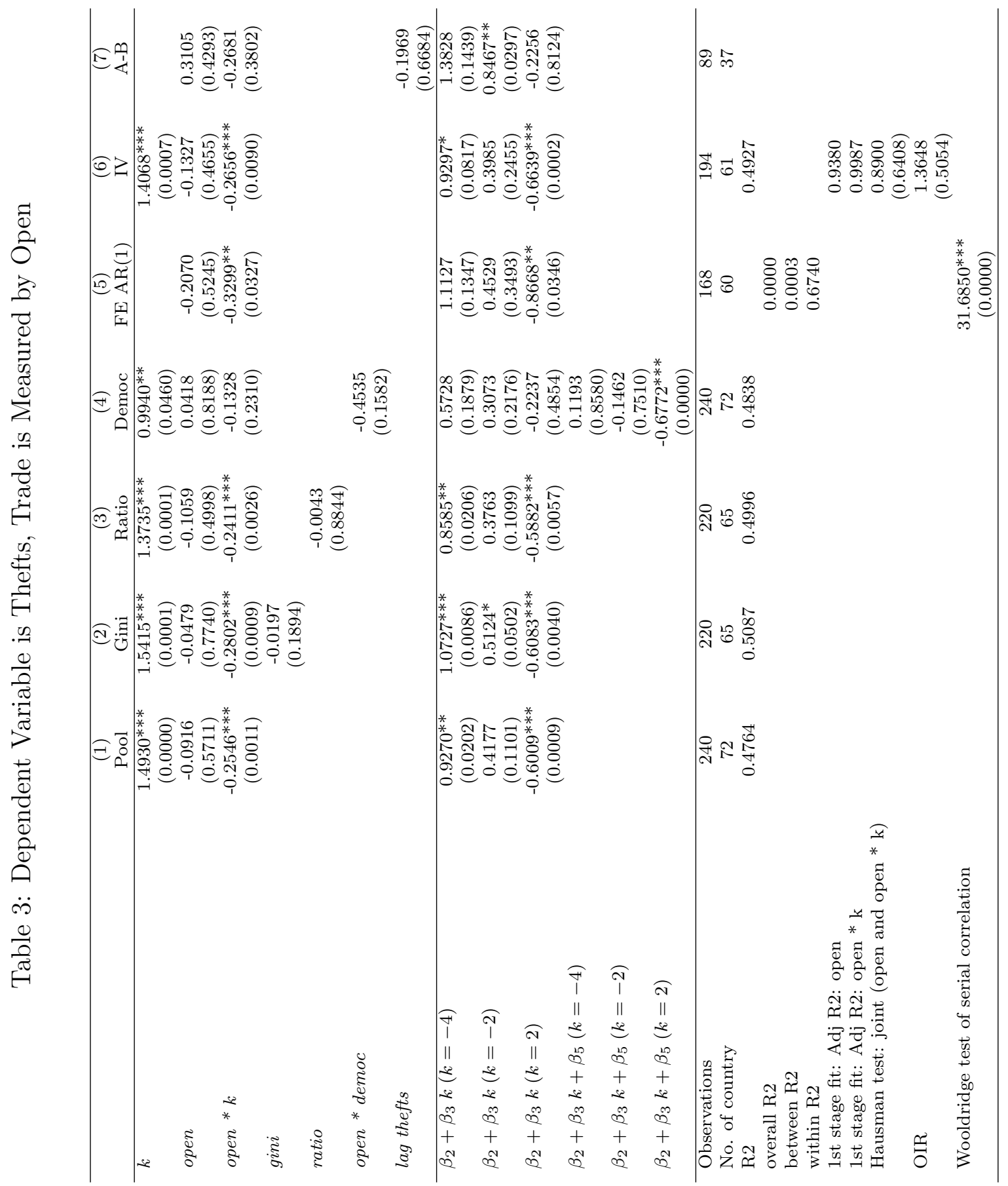




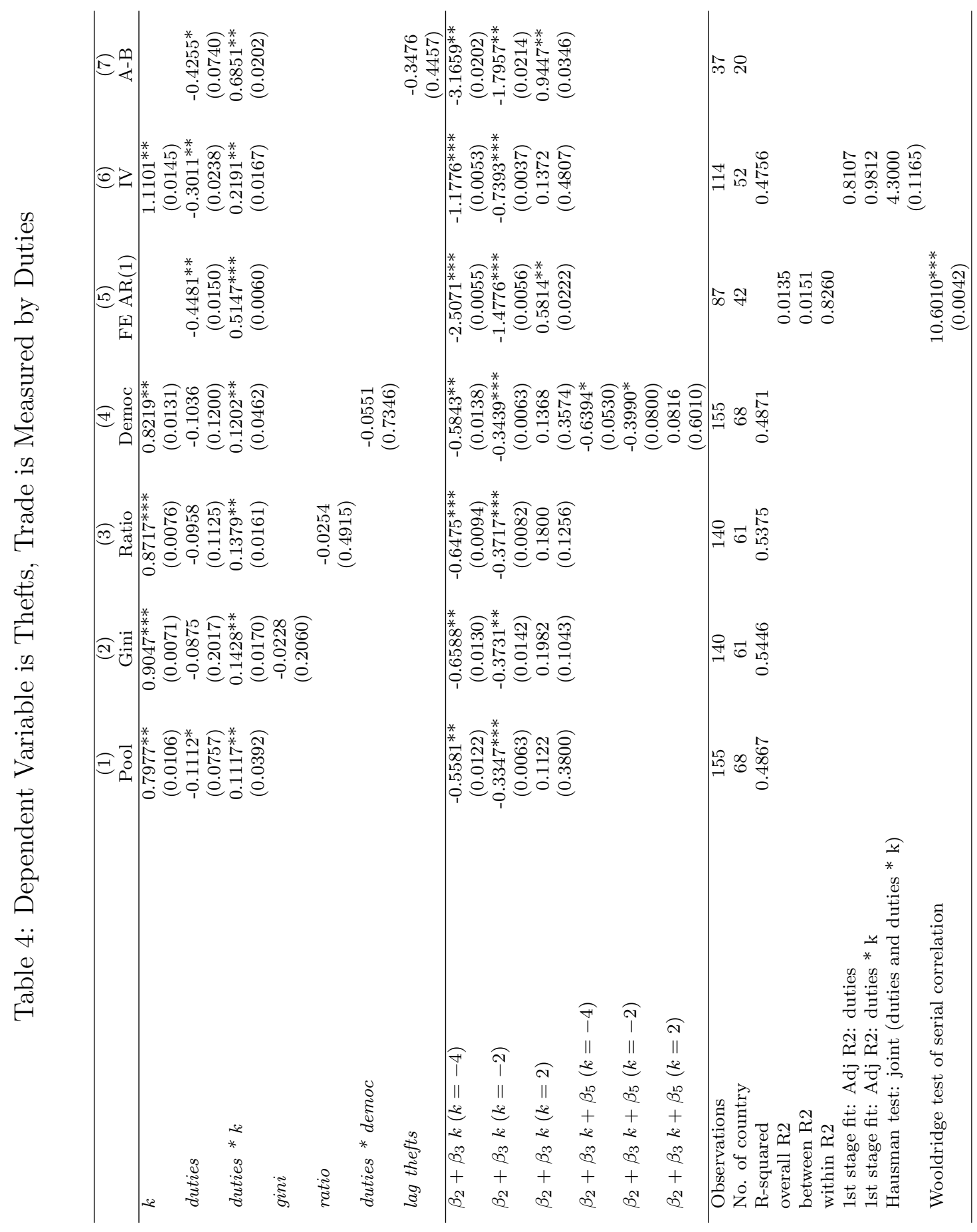




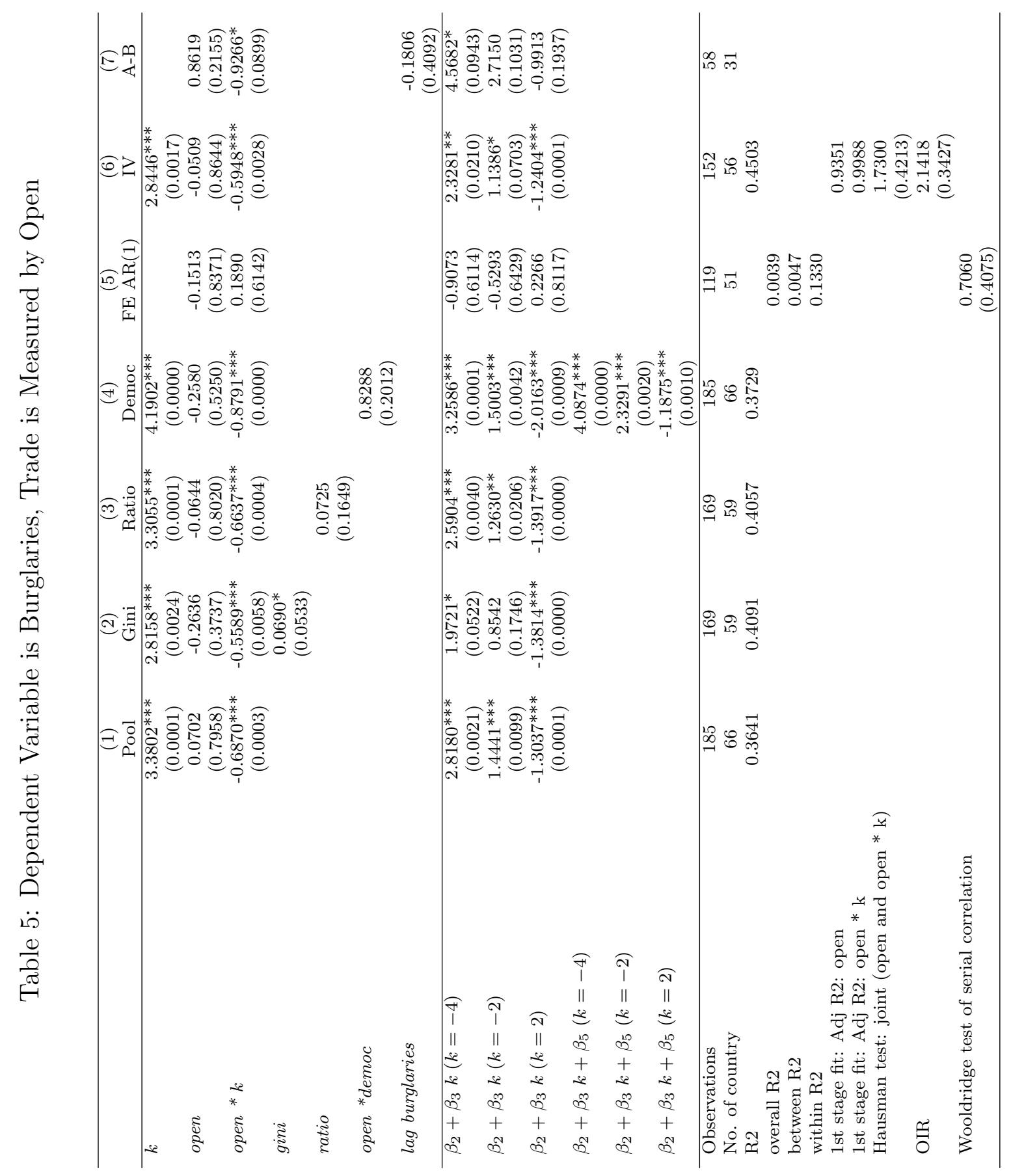




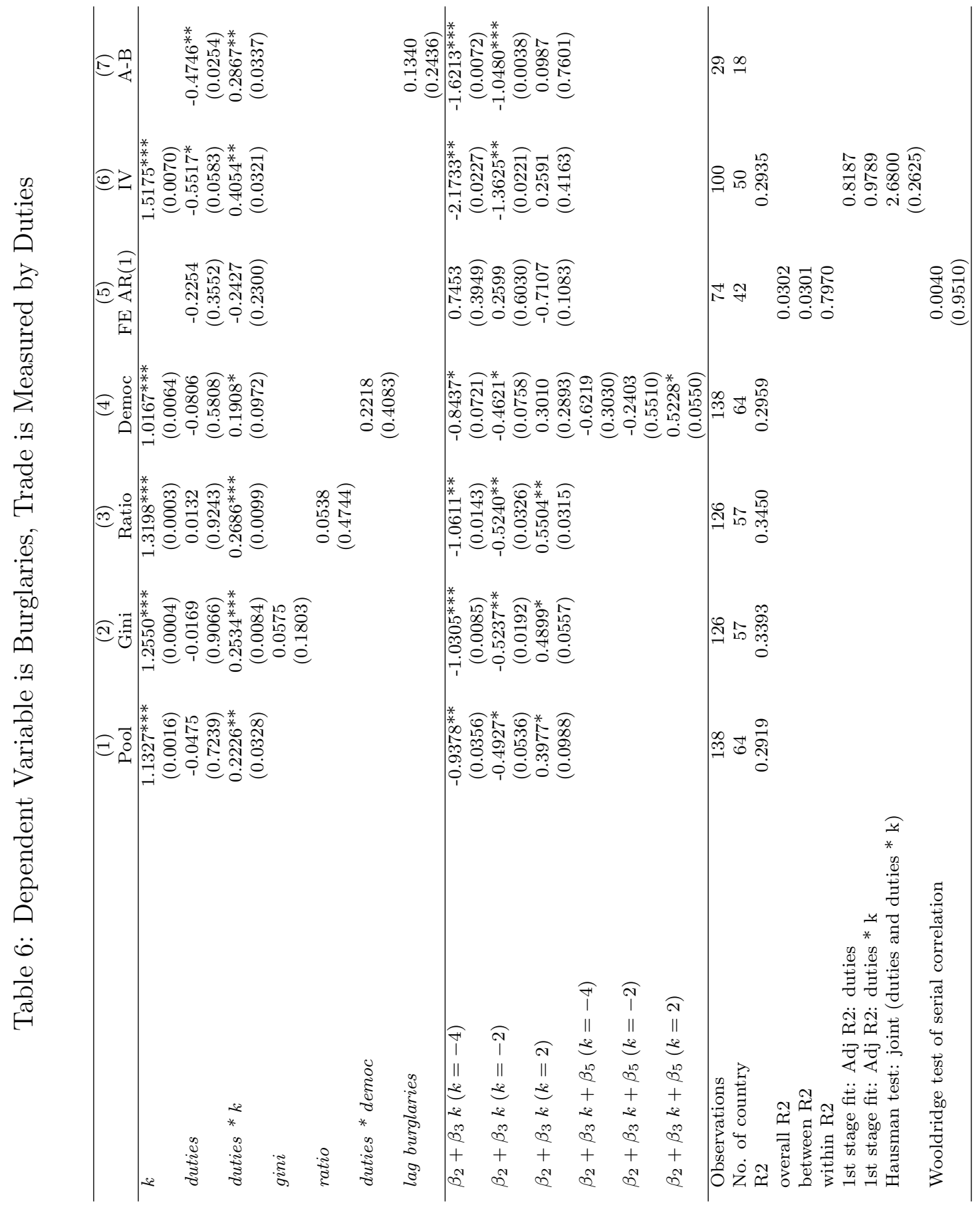


Table 7: Predicted Impacts on Theft due to Changes in Openness

\begin{tabular}{lcccc}
\hline Country & Period & $\begin{array}{c}\text { Increase in } \\
\text { Openness }(\%)\end{array}$ & $\begin{array}{c}\text { Increase in } \\
\text { Theft }(\%)\end{array}$ & $\begin{array}{c}\text { Predicted Increase } \\
\text { in Theft }(\%)\end{array}$ \\
\hline Thailand & $1982-2007$ & 109.1 & -38.6 & 22.1 \\
Bangladesh & $1982-2007$ & 78.2 & -112.1 & 49.8 \\
Philippines & $1982-2007$ & 58.1 & -160.0 & 10.1 \\
China & $1982-1997$ & 55.6 & -30.1 & 28.8 \\
Luxembourg & $1987-2007$ & 44.0 & -131.5 & -25.8 \\
Syria & $1987-1992$ & 40.6 & 4.4 & 16.7 \\
Turkey & $1987-2007$ & 39.3 & 107.4 & 6.5 \\
Morocco & $1992-2007$ & 33.9 & -25.0 & 5.6 \\
Switzerland & $1992-2007$ & 32.2 & -47.1 & -15.8 \\
Sri Lanka & $1987-2002$ & 25.4 & -24.9 & 6.1 \\
Netherlands & $1982-2007$ & 22.2 & -54.2 & -10.3 \\
Iceland & $1997-2007$ & 10.9 & -45.7 & -5.0 \\
Malaysia & $1982-1987$ & 6.9 & -14.1 & 1.2 \\
Norway & $1982-2007$ & -4.6 & -38.7 & 2.4 \\
Seychelles & $1982-1992$ & -9.9 & -24.3 & -2.8 \\
Pakistan & $1982-2002$ & -12.4 & -44.4 & -3.6 \\
Indonesia & $1982-1987$ & -16.4 & -58.8 & -8.7 \\
Barbados & $1982-2002$ & -24.0 & 21.3 & 11.0 \\
Egypt & $1982-1987$ & -39.9 & -7.4 & -14.0 \\
\hline
\end{tabular}


Table 8: Predicted Impacts on Burglaries due to Changes in Openness

\begin{tabular}{lcccc}
\hline Country & Period & $\begin{array}{c}\text { Increase in } \\
\text { Openness }(\%)\end{array}$ & $\begin{array}{c}\text { Increase in } \\
\text { Burglaries }(\%)\end{array}$ & $\begin{array}{c}\text { Predicted Increase } \\
\text { in Burglaries }(\%)\end{array}$ \\
\hline Thailand & $1987-2002$ & 76.2 & -180.9 & 65.9 \\
Malaysia & $1987-2007$ & 58.4 & -96.5 & 46.0 \\
China & $1987-2002$ & 52.5 & -3.9 & 90.0 \\
South Korea & $1992-2007$ & 45.1 & 85.8 & 26.1 \\
Syria & $1987-1992$ & 40.6 & -14.0 & 58.0 \\
Romania & $1992-2007$ & 38.9 & -80.8 & 24.1 \\
Egypt & $1987-2007$ & 38.3 & -45.4 & 48.5 \\
Switzerland & $1992-2007$ & 32.2 & -40.9 & -32.4 \\
Sri Lanka & $1987-2002$ & 25.4 & -8.1 & 24.4 \\
Netherlands & $1997-2007$ & 15.4 & -54.4 & -14.4 \\
Luxembourg & $2002-2007$ & 11.9 & -17.8 & -15.1 \\
Iceland & $1997-2007$ & 10.9 & -33.3 & 6.5 \\
Jordan & $1987-1997$ & 9.3 & -5.9 & 3.4 \\
El Salvador & $2002-2007$ & 7.4 & -417.2 & 3.1 \\
Colombia & $1992-2002$ & 7.2 & -64.6 & -4.9 \\
Norway & $1987-2007$ & 4.5 & -73.6 & 2.8 \\
Turkey & $2002-2007$ & 3.7 & 47.4 & -1.3 \\
Barbados & $1987-2002$ & 1.4 & 57.2 & -3.7 \\
Seychelles & $1987-1992$ & -3.4 & 6.3 & -1.8 \\
Zambia & $1992-2002$ & -3.8 & -43.9 & -17.0 \\
Pakistan & $1997-2002$ & -15.5 & -20.7 & -31.6 \\
Botswana & $1987-1992$ & -21.1 & -27.6 & \\
\hline
\end{tabular}




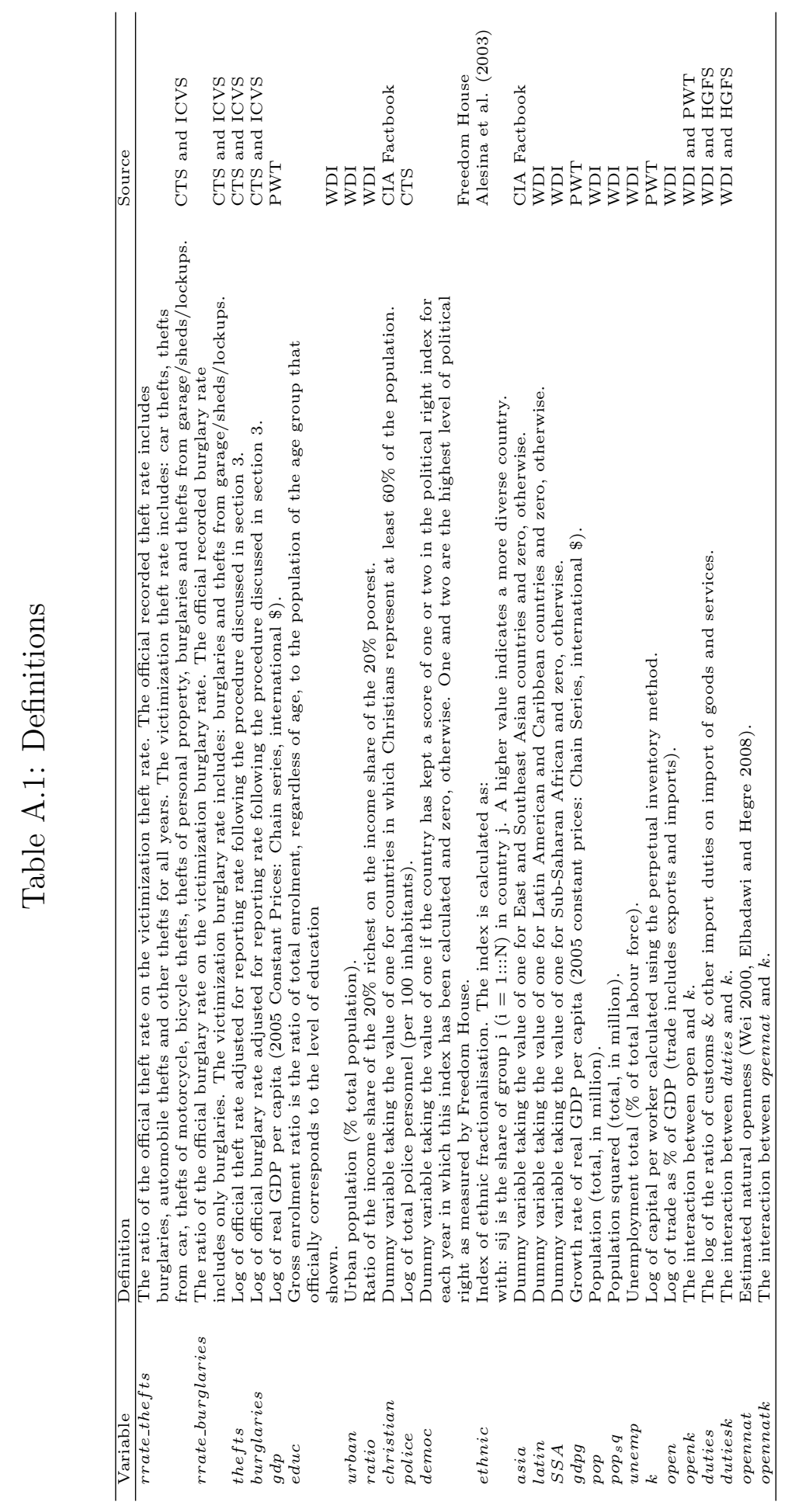


Table A.2: Full Regression Results

\begin{tabular}{|c|c|c|c|c|}
\hline & \multicolumn{2}{|r|}{$(2)$} & \multicolumn{2}{|c|}{$(3) \quad(4)$} \\
\hline & \multicolumn{2}{|c|}{ Thefts } & \multicolumn{2}{|c|}{ Burglaries } \\
\hline & Open & Duties & Open & Duties \\
\hline \multirow[t]{2}{*}{$g d p$} & -0.1894 & -0.2776 & -0.2240 & -0.0655 \\
\hline & $(0.2300)$ & $(0.1820)$ & $(0.4500)$ & $(0.83500$ \\
\hline \multirow[t]{2}{*}{ democ } & 0.0339 & 0.3493 & 0.1091 & 0.2736 \\
\hline & $(0.8770)$ & $(0.1900)$ & $(0.7650)$ & $(0.4320)$ \\
\hline \multirow{2}{*}{ ethnic } & $0.8089^{* *}$ & 0.3685 & $1.2815^{* *}$ & 0.7736 \\
\hline & $(0.0130)$ & $(0.3650)$ & $(0.0210)$ & $(0.1470)$ \\
\hline \multirow[t]{2}{*}{ asia } & $0.7023^{* *}$ & $1.0299^{* *}$ & 0.9465 & $1.0842^{* *}$ \\
\hline & $(0.0150)$ & $(0.0110)$ & $(0.1050)$ & $(0.0190)$ \\
\hline \multirow[t]{2}{*}{ latin } & $0.8046^{* * *}$ & $0.9352^{* * *}$ & 0.3170 & -0.1807 \\
\hline & $(0.0010)$ & $(0.0010)$ & $(0.5790)$ & $(0.6300)$ \\
\hline \multirow[t]{2}{*}{$S S A$} & $0.7400^{* *}$ & $1.3305^{* * *}$ & 0.9201 & $1.4347 * * *$ \\
\hline & $(0.0280)$ & $(0.0030)$ & $(0.1440)$ & $(0.0030)$ \\
\hline \multirow[t]{2}{*}{$g g d p$} & $-0.0319 *$ & $-0.1054^{* * *}$ & -0.0245 & -0.0767 \\
\hline & $(0.0680)$ & $(0.0010)$ & $(0.4850)$ & $(0.2050)$ \\
\hline \multirow[t]{2}{*}{ pop } & $-0.0034^{* *}$ & -0.0025 & $-0.0057^{* *}$ & $-0.0046^{*}$ \\
\hline & $(0.0180)$ & $(0.1220)$ & $(0.0350)$ & $(0.0880)$ \\
\hline \multirow[t]{2}{*}{ рор2 } & $0.0000^{* * *}$ & $0.0000^{* *} *$ & $0.0000^{* * *}$ & $0.0000^{* *}$ \\
\hline & $(0.0010)$ & $(0.0200)$ & $(0.0010)$ & $(0.0170)$ \\
\hline \multirow{2}{*}{ unemp } & 0.0032 & 0.0166 & $0.0373^{*}$ & $0.0560^{* *}$ \\
\hline & $(0.7490)$ & $(0.2040)$ & $(0.0620)$ & $(0.0220)$ \\
\hline \multirow[t]{2}{*}{$k$} & $1.4930^{* * *}$ & $0.7977^{* * *}$ & $3.3802^{* * *}$ & $1.1327^{* * *}$ \\
\hline & $(0.0000)$ & $(0.0000)$ & $(0.0000)$ & $(0.0010)$ \\
\hline \multirow[t]{2}{*}{ open } & -0.0916 & & 0.0702 & \\
\hline & $(0.4420)$ & & $(0.7600)$ & \\
\hline duties & & $\begin{array}{c}-0.1112^{*} \\
(0.0820)\end{array}$ & & $\begin{array}{l}-0.0475 \\
(0.6860)\end{array}$ \\
\hline open $k$ & $\begin{array}{c}-0.2546^{* * *} \\
(0.0000)\end{array}$ & & $\begin{array}{c}-0.6870^{* * *} \\
(0.0000)\end{array}$ & \\
\hline duties $k$ & & $\begin{array}{c}0.1117^{* *} \\
(0.0250)\end{array}$ & & $\begin{array}{c}0.2226^{* *} \\
(0.0140)\end{array}$ \\
\hline cons & $11.5772^{* * *}$ & $11.6105^{* * *}$ & $8.7095^{* * *}$ & $7.5598^{* * *}$ \\
\hline Observations & $\frac{(0.0000)}{240}$ & $\frac{(0.0000}{155}$ & $\frac{(0.0020)}{185}$ & $\frac{(0.0010)}{138}$ \\
\hline
\end{tabular}

